\title{
SISTEM PENGUPAHAN OUTSOURCING DALAM PERSPEKTIF ISLAM (STUDI KASUS PADA PT. MAHAKAM KENCANA INTAN PADI SURABAYA) 1]
}

\author{
M. Sahirul Alim \\ Mahasiswa Program Studi S1 Ekonomi Islam-Fakultas Ekonomi dan Bisnis-Universitas Airlangga \\ Email: m.sahirul.alim-10@feb.unair.ac.id \\ Sri Herianingrum \\ Departemen Ekonomi Syariah - Fakultas Ekonomi dan Bisnis - Universitas Airlangga \\ Email: Sri.herianingrum@feb.unair.ac.id
}

\begin{abstract}
This study aims to analyze the implementation of wage system outsourcing in PT Mahakam Kencana Intan Padi Surabaya in Islamic Perspective.

Methods of research for this study used a qualitative approach with case study methods and descriptive analyzes were conducted information about wage system outsourcing in PT Mahakam Kencana Intan Padi Surabaya in depth, observed and validated data by triangulation.

The results showed that implementation of oursourcing labor remuneration at PT Mahakam Kencana Intan Padi Surabaya in Islamic Perspective according based Al-Quran and Al-Hadith. The indicators used by the terms of feasibility of minimum wages and equity among workers. Insights justice in Islamic perspective is described comparative labor positions corresponding salaries earned. Payment of salaries in PT Mahakam Kencana Intan Padi accordance timelines. PT Mahakam Kencana Intan Padi is not sharia company but the results of the research conclusion is the wage system in PT Mahakam Kencana Intan Padi according Islamic perspective.
\end{abstract}

\section{PENDAHULUAN}

\section{Latar Belakang}

Perkembangan

perekonomian

Indonesia merupakan suatu hasil positif dari kegiatan yang dilakukan dalam sektor pembangunan. Salah satu di antara sektor pembangunan yang memiliki peranan penting dalam meningkatkan pertumbuhan perekonomian di tanah air adalah sektor industri, jasa dan perdagangan. Hal ini dapat diketahui dari berbagai bentuk pelaku usaha dalam meningkatkan pendapatan dan pengembangan usahanya seperti adanya persaingan antar perusahaan. (Abdurrahman, 2009 : 68)

Masalah pengupahan adalah masalah yang tidak pernah selesai diperdebatkan oleh pihak manajemen, apapun bentuk organisasinya. Upah 1) Jurnal ini merupakan bagian dari skripsi dari M.Sahirul Alim. NIM 041014158 yang diuji pada 02 Mei 2017 seolah-olah kata-kata yang selalu membuat pihak manajemen perusahaan berpikir ulang dari waktu ke waktu untuk menetapkan kebijakan tentang upah. (Baqir , 2007 :159)

Pada banyak kasus yang ditemui periode terakhir, banyak para karyawan atau tenaga kerja yang tidak mendapatkan perlakuan dan porsi yang layak dalam dinamika perekonomian. Dalam kenyataannya jumlah gaji yang relatif tetap tidak sebanding dengan kebutuhan hidup mereka yang selalu bertambah, hal itu menyebabkan kualitas kesejahteraan rakyat menjadi semakin rendah. Sedangkan di satu sisi dalam sebuah perusahaan juga sangat membutuhkan sumber daya manusia yang baik yaitu berkualitas dan mempunyai etos kerja yang tinggi. Islam 
Alim, et al/Jurnal Ekonomi Syariah Teori dan Terapan Vol. 5 No. 6 Juni 2018: 499-510; SISTEM PENGUPAHAN OUTSOURCING DALAM PERSPEKTIF ISLAM (STUDI KASUS PADA PT. MAHAKAM KENCANA INTAN PADI SURABAYA)

dalam syari'atnya justru sangat dalam perspektif Ekonomi Islam yang memperhatikan nasib seorang karyawan atau tenaga kerja yang bekerja di sebuah perusahaan yang sekarang ini banyak diterapkan di masyarakat yaitu karyawan yang dialih dayakan atau disewakan kepada perusahaan lain. (Muba, 2010 : 128)

PT. Mahakam Kencana Intan Padi Surabaya merupakan perusahaan yang bergerak dalam bidang Outsourcing yang terbagi menjadi 17 divisi dan 48 cabang perusahaan dari seluruh Indonesia. Berdasarkan visi dan misi perusahaan ini menghasilkan tenaga kerja secara profesional dengan kebutuhan perusahaan dalam pengembangan SDM. Namun setiap tenaga kerja yang berasal dari PT. Mahakam pada sistem penggajian mendapatkan potongan dari perusahaan tersebut. Fenomena tersebut membuat tertarik penulis untuk melakukan penelitian jika dipandang dengan prespektif Islam di PT. Mahakam Intan Padi.

Peneliti ingin menganalisis sistem pengupahan tenaga kerja yang ada dalam sebuah perusahaan Outsourcing dalam perspektif Ekonomi Islam, karena masalah ketenagakerjaan disini memang suatu masalah yang sangat kompleks dan harus mendapat perhatian khusus terutama dalam memberikan aware kepada para tenaga kerja tentang sistem pengupahan. Skripsi ini menganalisis sistem pengupahan tenaga kerja yang ada dalam sebuah perusahaan Outsourcing 
Alim, et al/Jurnal Ekonomi Syariah Teori dan Terapan Vol. 5 No. 6 Juni 2018: 499-510; SISTEM PENGUPAHAN OUTSOURCING DALAM PERSPEKTIF ISLAM (STUDI KASUS PADA PT. MAHAKAM KENCANA INTAN PADI SURABAYA)

orang-orang mukmin akan melihat menyatakan bahwa Nabi SAW bersabda: pekerjaanmu itu, dan kamu akan dikembalikan kepada (Allah) yang mengetahui akan yang ghaib dan yang nyata, lalu diberitakan-Nya kepada kamu apa yang telah kamu kerjakan."

Penjelasan yang diungkapkan Quraish Sihab yaitu makna dari ayat di atas adalah bahwa Allah memerintahkan kepada mahluknya untuk berlombalomba mencari pekerjaan yang halal karena sesungguhnya Allah dan Rasul melihat apa yang sedang kamu kerjakan, dan akan memberikan balasan atas apa yang telah kamu kerjakan

Selain itu ayat tentang
pengupahan dalam Islam juga
terkandung dalam Surat Yusuf ayat 72 yanf Artinya : "Penyeru-penyeru itu berkata: "Kami kehilangan piala Raja, dan siapa yang dapat mengembalikannya akan memperoleh bahan makanan (seberat) beban unta, dan aku menjamin terhadapnya".

Makna yang ada dalam ayat di atas menurut Quraish Sihab adalah bahwa Allah akan memberikan jaminan atau mengembalikan sesuai dengan jerih payah seseorang terhadap siapa saja yang bersungguh-sungguh dalam mengerjakan sesuatu yang halal dalam jalan Allah.

\section{Menurut Al - Hadist}

Dari Abdullah Bin Mas'ud meriwayatkan dari Hadits Nabi SAW yang bersabda : "Mencari rezeki yang halal adalah kewajiban sesudah kewajiban." (Baihaqi). Selanjutnya Abu Dzar "Mereka (para pekerja atau tenaga kerja) adalah saudara-saudara kalian. Allah telah menempatkan mereka di bawah kekuasaanmu, berilah mereka makanan seperti makananmu, berpakaian seperti pakaianmu, dan janganlah mereka kalian bebani dengan sebuah pekerjaan diluar kemampuan dan perjanjian yang telah diperjanjikan."

\section{Konsep Upah Dalam Perspektif Islam}

Ghufron (2009: 21), yaitu, Pertama, perbuatan tersebut harus jelas batas waktu pekerjaan, misalnya bekerja shift malam dan siang, atau satu bulan. Dan harus jelas jenis pekerjaannya, misalnya pekerjaan menjaga keamanan, menjadi supir, dan lain sebagainya. Dalam hal yang disebutkan terakhir ini tidak disyaratkan adanya batas waktu pengerjaannya. Pendek kata, dalam hal ijarah pekerjaan, diperlukan adanya job discription (uraian pekerjaan). Tidak dibenarkan mengupah seorang dalam periode waktu tertentu dengan ketidakjelasan pekerjaan. Sebab ini cenderung menimbulkan tindakan kesewenangan yang memberatkan pihak pekerja.

\section{Aspek Kelayakan}

Kehidupan layak yang diperoleh oleh pengusaha hendaknya juga diperoleh oleh karyawan selaku keluarga yang ada dibawah asuhannya (pengusaha) meski takarannya tidak sama, namun pemenuhan kehidupan yang layak merupakan kewajiban yang harus dipenuhi. (Heidjachman R. , 2002:86) 
Alim, et al/Jurnal Ekonomi Syariah Teori dan Terapan Vol. 5 No. 6 Juni 2018: 499-510; SISTEM PENGUPAHAN OUTSOURCING DALAM PERSPEKTIF ISLAM (STUDI KASUS PADA PT. MAHAKAM KENCANA INTAN PADI SURABAYA)

kelayakan lebih menekankan

ketika berbicara mengenai perbedaan

pada aspek tercukupinya kebutuhan pekerja dan keluarganya serta aspek kesesuaian dengan norma-norma yang ada. Maka dari itu Islam menjadikan unsur kelayakan sebagai parameter tersendiri pada tahapan-tahapan pemberian upah kepada pekerja. (Heidjachman R. ,2002:88)

\section{Kelayakan Perusahaan}

Heidjachman R (2002: 90) Kelayakan menurut perusahaan adalah menggunakan peraturan pemerintah tentang upah minimum regional, karena apabila upah pada perusahaan lain lebih tinggi maka berakibat kesulitan bagi perusahaan untuk memperoleh tenaga kerja yang di butuhkan.

\section{Kelayakan Tenaga Kerja}

Suad Husnan (2002 : 16) Disamping kelayakan dalam perusahaan, kelayakan dari aspek tenaga kerja perlu di perhatikan. Kelayakan pada tenaga kerja berkaitan dengan standar hidup seperti kebutuhan pokok. Tenaga kerja juga akan menili kelayakan dengan membandingkan upah dengan perusahaan lain.

\section{Aspek Keadilan}

Zulkhaeril (2009 : 56) Adil selain artinya yang luas juga aspek yang tercakup tidaklah sempit. Hampir semua aspek selalu terkait adanya unsur adil. Karena adil merupakan satu unsur yang sifatnya krusial dan sering menjadi pemicu konflik intern perusahaan. Sangat tidak mudah bagi kita menentukan keadilan

upah karyawan. Seperti yang telah terpapar di atas, bahwa hubungan antara pengusaha dan karyawan adalah kekelvargaan, kemitraan dan keduanya tercipta simbiosis mutualisme. Maka dari itu, tidak boleh satu pihak mendzalimi dan merasa didzalimi oleh pihak lainnya. Keduanya saling membutuhkan dan diantaranya harus tercipta rasa saling menguntungkan. Dalam hal ini konsep keadilan menjadi hal mutlak yang haru dipenuhi.

Tenaga kerja sudah mendapatkan keadilan ketika pengorbanan (input) telah sesuai dengan penghasilan (output). Aspek keadilan pada tenaga kerja adalah waktu tenaga kerja, tenaga kerja akan membandingkan penghasilan dengan rekan yang lain, misalkan upah sama tetapi beban kerja lebih berat, tentunya tenaga tersebut belum merasa adil.

\section{Penelitian Terdahulu}

Penelitian pertama tentang sebuah studi kasus yang dilakukan oleh Zulkhaeril (2011 : 08) tentang pengupahan karyawan dalam perspektif Fiqih Muamalah yang dilakukan dengan metode studi kasus pada sebuah kawasan home industri. Zulkhairil dalam penelitian ini menggunakan metode kepustakaan dan metode lapangan dengan pendekatan kualitatif. Perbedaan yang membedakan dengan peneliti adalah metode yang digunakan, karena metode yang digunakan penelitian ini menggunakan metode kepustakaan. 
Alim, et al/Jurnal Ekonomi Syariah Teori dan Terapan Vol. 5 No. 6 Juni 2018: 499-510; SISTEM PENGUPAHAN OUTSOURCING DALAM PERSPEKTIF ISLAM (STUDI KASUS PADA PT. MAHAKAM

KENCANA INTAN PADI SURABAYA)

Namun persamaannya adalah sama sama menggunakan pendekatan kualitatif dengan wawancara kepadapihak pihak terkait di lapangan .

Penelitian selanjutnya adalah dilakukan oleh Rudi Sugiarto (2012: 09) tentang Pengupahan pada PT Permata Indonesia dalam Ekonomi Islam. Metode penelitian ini menggunakan pendekatan kualitatif deskriptif. Yang dalam penelitiannya juga membahas tentang tata cara pengupahan yang selama ini terjadi yang harus diketahuimasyarakat luas agar tidak ada salah presepsi.

\section{Kerangka Pemikiran}

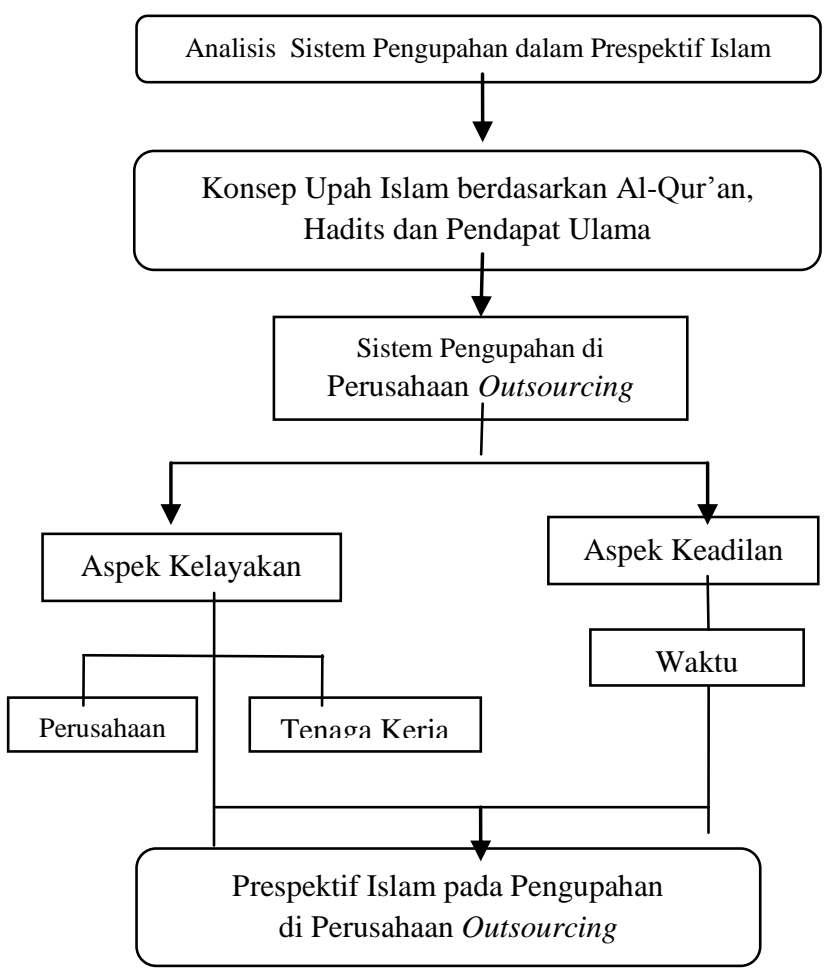

Gambar 2.1

\section{Kerangka Berpikir}

III METODE PENELITIAN

Pendekatan penelitian ini menggunakan metode kualitatif Menurut
Sugiyono (2012: 9), metode penelitian kualitatif digunakan untuk memeliti kondisi obyek yang alamiah, (sebagai lawannya adalah eksperimen) dimana peneliti adalah sebagai instrumen kunci.

Strategi penelitian kualitatif yang digunakan dalam penelitian ini adalah studi kasus karena penelitian ini bertujuan untuk menjawab :"Bagaimana analisis sistem pengupahan Outsourcing pada PT. Mahakam Kencana Intan Padi berdasarkan perspektif Ekonomi Islam?". Studi kasus menjadi strategi yang sangat cocok karena menurut Yin (2013:8) studi kasus relevan untuk penelitian dengan pertanyaan "bagaimana".

\section{Ruang Lingkup Penelitian}

Objek penelitian dilakukan pada PT. Mahakam Kencana Intan Padi yang berlokasi di Jl. Tenggilis No. 5 Surabaya, Jawa Timur. Ruang lingkup penelitian ini hanya mencakup atas sistem pengupahan yang dilakukan oleh PT. Mahakam Kencana Intan Padi Surabaya.

\section{Analisis dan Teknik pengumpulan data}

Sumber data yang digunakan untuk penelitian ini adalah data primer. Menurut Wangsa dan Ming Kuan (2011:12), "Data primer adalah data utama yang penulis peroleh dari pihakpihak yang bersangkutan pada perusahaan yang menjadi objek penelitian".

Menurut Sugiyono (2012 : 22) Selain data primer, data yang digunakan dalam penelitian ini adalah data sekunder. Data sekunder adalah data yang diperoleh dari 
Alim, et al/Jurnal Ekonomi Syariah Teori dan Terapan Vol. 5 No. 6 Juni 2018: 499-510; SISTEM PENGUPAHAN OUTSOURCING DALAM PERSPEKTIF ISLAM (STUDI KASUS PADA PT. MAHAKAM

KENCANA INTAN PADI SURABAYA)

studi literatur, dengan mempelajari buku-

buku dan sumber lain yang berkaitan.

Data ini mendukung keakuratan dan

kebenaran data primer

Teknik pengumpulan data

1. Wawancara

Teknik yang digunakan adalah Wawancara mendalam (in-depth interview) yaitu proses memperoleh keterangan untuk tujuan penelitian dengan cara tanya jawab sambil bertatap muka antara pewawancara dengan informan dengan atau tanpa menggunakan pedoman (guide) wawancara, dimana pewawancara dan informan terlibat dalam kehidupan sosial yang relatif lama (Saeful, 2009:6).

\section{Dokumentasi}

Dokumentasi digunakan oleh peneliti karena memudahkan peneliti untuk lebih memahami sumber-sumber sekunder lain (Sugiyono, 2012 : 58).

3. Studi Literatur

Peneliti melakukan penelitian dengan cara mengumpulkan dan mempelajari buku-buku yang berhubungan dengan sistem pengupahan.

IV. PEMBAHASAN

Upah Minimum PT. Mahakam Kencana Intan Padi

Hasil perolehan data mengenai upah minimum yang diterapkan pada PT. Mahakam Kencana Intan Padi berdasarkan data interview dan dokumentasi sebagai berikut;
Hasil wawancara dari Kepala Bagian Kevangan:

"...lya, kita menggaji karyawan sesuai dengan UMR khususnya yang ditetapkan di Surabaya, dan perusahaan kita menetapkan upah ini ada dasarnya yaitu mengacu pada surat keputusan Gubernur."

Hasil wawancara di atas juga dilakukan pada pihak Kepala Personalia atau HRD sebagai berikut:

"...Tidak, sebenarnya aturan yang digunakan diperusahaan ini cukup berpedoman kepada upah minimum yang ada di kabupaten atau kota sesuai dengan wilayah masing2. Semuanya sudah berdasarkan peraturan Gubenur Jatim no.72 th 2012 tentang upah minimum kabuten/kota di jawa timur"

Hasil wawancara dengan Kepala Bagian Keungan dan HRD di atas juga didukung langsung dengan wawancara tenaga kerja sebagai berikut;

"...Kalau dibilang mencukupi sih iya, mencukupi sebetulnya jika saya bisa dan mempunyai prestasi yang baik di PT. Mahakam Kencana Intan Padi akan menghargainya".

Aspek Keadilan Bagi Pekerja di PT. Mahakam Kencana Intan Padi

Pada aspek keadilan bagi pekerja menyangkut perbedaan upah karyawan dan kondisi kerja pada PT. Mahakam Kencana Intan Padi diperoleh data hasil dari dari tenaga kerja PT. Mahakam Kencana Padi sebagai berikut;

"....Siapa yang ingin gaji tinggi, semuanya pasti mau. Tapi di sini menurut 
Alim, et al/Jurnal Ekonomi Syariah Teori dan Terapan Vol. 5 No. 6 Juni 2018: 499-510; SISTEM PENGUPAHAN OUTSOURCING DALAM PERSPEKTIF ISLAM (STUDI KASUS PADA PT. MAHAKAM KENCANA INTAN PADI SURABAYA)

saya adil karena gaji yang saya terima pengupahan, supaya tidak menghambat sesui bahkan di atas UMR yaitu 3, 5 jam kerja sesuai, kalau saya harus lembur itu pun juga ada upahnya. Di sini juga tidak mengharuskan karyawan lembur. Jika pekerjaan dan waktu kerja sudah selesai ya sudah kita pulang".

Berdasarkan dari wawancara di atas bahwa pemberian gaji di PT. Mahakam adil bahkan melebihi UMR.

\section{Ketepatan Waktu}

Pada aspek ketepatan waktu penggajian yaitu berdasarkan data diperoleh dari hasil wawancara terhadap Kepala Keuangan sebagai berikut;

"...lya, Selama ini alur dan proses pengupahan atau pengggajian di perusahaan ini selalu tepat waktu, hal ini dilakukan perusahaan karena supaya tidak mengganggu kinerja di lokasi dan supaya menjaga kualitas dan kepercayaan tenaga kerja yang bekerja di perusahaan kami"

Hasil wawancara di atas juga sesuai dengan hasil wawancara kepada kepala personalia sebagai berikut;

"...ya, tepat waktu. Sesuai dengan kesepakatan yang ada di dalam legal office antar pemakai jasa dan penyedia jasa yang di dalamnya dibahas tentang ada atau tidaknya dana talangan yang harus dilakukan penyedia jasa Iperuasahaan PT. MKIP sendiri".

Berdasarkan kedua hasil wawancara di atas dapat diketahui bahwa perusahaan PT. Mahakam Kencana Intan Padi Surabaya mengedepankan ketepatan waktu kinerja perusahaan. Dan pada sisi lain dengan ketepatan pengupahan juga menjaga kulaitas perusahaan dan kepercayaan bagi karyawan. Jika ketepatan waktu menjadi hal yang komitmen bagi perusahaan, tentu juga menciptakan kepuasan kerja kepada tenaga kerja.

Memang ada potongan bagi tenaga kerja PT. Mahakam Kencana Padi Surabaya, sehingga ada beberapa karyawan yang protes sebab kurang paham proses penggajian. Berdasarkan dari hasil wawancara kepada Bu Dian Bagian Kepala Keuangan sebagai berikut;

"...Pernah, kadang-kadang tenaga kerja atau karyawan sering kali tidak paham mengenai perhitungan pembayaran, mereka seringkali protes akan potongan yang diberikan. Padahal kita tidak pernah memotong fee yang diberikan dan potongan yang ada pun kita mintakan dari perusahaan terkait selaku pemakai jasa, potongan tersebut meliputi adanya pendidikan dan pelatihan dengan kualitas dan sistem yang tinggi. Juga adanya jaminan kesehatan dan tunjangan hari tua. Kita tidak pernah mengambil hak tenaga kerja karena kita juga punya kontrak perjanjian hitam di atas putih yang disahkan oleh badan hukum. Jadi kita sebagai penyedia jasa memberikan upah sesuai dengan perjanjian kontrak yang disepakati dari awal ketika tenaga kerja/karyawan tersebut mendatangani kontrak kerja". 
Alim, et al/Jurnal Ekonomi Syariah Teori dan Terapan Vol. 5 No. 6 Juni 2018: 499-510; SISTEM PENGUPAHAN OUTSOURCING DALAM PERSPEKTIF ISLAM (STUDI KASUS PADA PT. MAHAKAM KENCANA INTAN PADI SURABAYA)

Data hasil penelitian yang diperoleh dari kepala personalia sebagai berikut:

"...ya iya pasti, kalau tidak sesuai dengan kontrak di awal mana tenaga kerja mau, yang pasti kita sebagai pihak penyedia jasa telah melaksanakan sesuai dengan perjanjian kontrak yang diberikan kepada tenaga kerja sesuai dengan ketentuan pemakai jasa".

Hal ini didukung juga dengan wawancara oleh salah satu karyawan :

"..kalau gajian selalu tanggal 25 walaupun kadang masuknya sore hari tapi mestinya selalu tanggal 25, kalau ada tanggal merah di hari itu biasanya dimajukan penggajiannya"

Dari hasil wawancara di atas bahwa terdapat perjanjian kontrak yang seharusnya diketahui isinya oleh karyawan. Namun tenaga kerja kadang tidak memperhatikan isinya yaitu pemotongan gaji bukan pemotongan gaji fee tenaga kerja tetapi meliputi adanya pendidikan dan pelatihan dengan kualitas dan peningkatan sistem yang tinggi.

Aspek Kelayakan Pengupahan pada PT.

Mahakam Kencana Intan Padi

Kelayakan Tenaga Kerja

Pada aspek ini diperoleh data dari hasil wawancara oleh HRD sebagai berikut

"...dalam hakikatnya kelayakan perusahaan disini sudah jelas karena perusahaan sudah menempatkan tenaga kerja dengan sebagaimana mestinya. Perusahaan kami tidak pernah menerima tenaga kerja wanita untuk dijadikan security"
Kelayakan lebih menekankan pada aspek tercukupinya kebutuhan pekerja dan keluarganya serta aspek kesesuaian dengan norma-norma yang ada.

\section{Kelayakan Perusahaan}

Data perolehan hasil wawancara dalam aspek ini didukung dengan data wawancara kepada kepala personalia atau HRD sebagai berikut;

"...semua gaji karyawan /tenaga kerja di tempat kami sudah sesuai dengan UMK dan berpedoman pada undangundang pemerintah kalau tidak sesuai UMK bisa ditindak dengan aparat instansi yang terkait dengan ketenagakerjaan dan akan berpengaruh pada kinerja karyawan kita".

Selanjutnya

wawancara disampaikan oleh koordinator tenaga kerja (security) sebagai berikut :

"... untuk gaji saya cukup untuk mencukupi kebutuhn pokok keluarga saya, standar gaji yang saya terima rata rata juga sama seperti gaji karyawan pada umumnya karna disini acuannya pada UMR surabaya"

Berdasarkan hasil wawancara di atas bahwa penentuan upah disesuaikan dengan peraturan daerah wilayah Surabaya. Dalam menentukan gaji dan penegakkan terhadap hak-hak karyawan. Sedangkan yang menjadi peraturan mengacu pada Peraturan Gubernur (Pergub) Jatim Nomor 72 Tahun 2014. Diantara isi dari undang-undang tersebut adalah pelarangan upah lebih rendah dari UMK dan mewajibkan pemberian gaji 
Alim, et al/Jurnal Ekonomi Syariah Teori dan Terapan Vol. 5 No. 6 Juni 2018: 499-510; SISTEM PENGUPAHAN OUTSOURCING DALAM PERSPEKTIF ISLAM (STUDI KASUS PADA PT. MAHAKAM KENCANA INTAN PADI SURABAYA)

pada karyawan lebih dari Upah Minimal

Kota (UMK). Pada hasil wawancara kepada kepala personalia atau HRD dan koordinaor security yang juga termasuk salah satu tenaga kerja yang bekerja di perusahaan outsourcing menunjukkan tindakan pemerintah jika tidak mengikuti peraturan mengenai pengupahan terhadap tenaga kerja.

Analisis Prespektif Islam terhadap Sistem Pengupahan PT. Mahakam Kencana Intan Padi Surabaya

Dari hasil wawancara kepada karyawan juga merasa mencukupi kebutuhan sehari-hari mereka. UMR dijadikan ukuran pemerintah daerah wilayah Surabaya, karena standarisasi kebutuhan masyarakat tercukupi kalau pendapatan masyarakat berdasarkan UMR kota Surabaya tersebut.

Prespektif Islam gaji tenaga kerja diukur berdasarkan hadits Rosulullah yang diriwayatkan oleh Bukhori dan Muslim yang maksudnya yaitu setiap muslim wajib bekerja, pekerja dan pemberi pekerjaan sebagai saudara, maka pemberi pekerjaan disuruh memberi makanan seperti makananmu, berpakaian seperti pakaianmu, dan dilarang membebani pekerjaan di luar kemampuan tenaga kerja. Jadi dari maksud hadits tersebut dapat dipahami bahwa majikan memberikan makanan, pakaian yang layak dan dilarang membebani pekerja. Hal tersebut juga senada dengan pemikiran tokoh Islam al-Nabhani yaitu pemberian upah minimal untuk kebutuhan primer.
Analisis Keadilan pada Pengupahan PT. Mahakam Kencana Intan Padi

Ada perbandingan antar pengupahan tenaga kerja yang satu dengan yang lainnya, namun perbandingannya tidak terlalu besar. Karena disesuaikan dengan tugas dan tanggung jawabnya masing-masing. Dan selisihnya hanya sebesar Rp 100.000,-. Jadi tenaga kerja juga merasa mendapatkan keadilan. Seperti pada koordinator security bertugas sebagai keamanan dengan penambahan tugas sebagai koordinator.

Pada prespektif Islam juga memandang bahwa segala sesuatu pekerjaan diukur dengan jerih payahnya, bahkan pemberian lebih pada tenaga kerja merupakan hal yang lebih baik. Hal tersebut tercantum dalam al-Qur'an Surat Yusuf ayat 72 yang memberikan pengertian bahwa Allah memberikan Jaminan dan mengembalikan sesuai dengan jerih payah siapa saja yang sungguh-sungguh mengerjakan sesuatu. Ayat tersebut diterapkan pada majikan dan karyawan bahwa segala sesuatu diukur dengan jerih payahnya.

Dalam al-Qur'an Surat Yusuf ayat 72 juga sesuai dengan hasil wawancara kepada Kepala Personalia atau HRD sebagai berikut;

"...menurut saya ya sudah sesuai, karena selama ini jam kerja dan upah yang diterima tentunya selalu sesuai dengan kesepakatan awal. Kita tidak mungkin mempekerjkan tenaga kerja lebih dari jam kerja terkecuali keadaan 
Alim, et al/Jurnal Ekonomi Syariah Teori dan Terapan Vol. 5 No. 6 Juni 2018: 499-510; SISTEM PENGUPAHAN OUTSOURCING DALAM PERSPEKTIF ISLAM (STUDI KASUS PADA PT. MAHAKAM KENCANA INTAN PADI SURABAYA)

tertentu yang mengharuskan untuk

Kelayakan pada pengupahan PT. tenaga kerja bekerja lebih dari jam kerja misalkan lembur, itupun akan dihitung tiap jamnya untuk upah lemburnya".

Perbandingan di perusahan ini juga berdasarkan pengukuran tugas berdasarkan hasil penelitian gaji pokok tetap sama dan hanya ada perbedaan tunjangan dan insentif. Dari hasil wawancara kepada Kepala Personalia atau HRD bagi yang kerja lembur dihitung dan disesuaikan pada tiap jamnya.

\section{Ketepatan Waktu}

Berdasarkan dari hasil wawancara kepada Kepala Keuangan PT. Mahakam Kencana Intan Padi bahwa sistem pengupahannya mengedepankan ketepatan waktu agar tidak menghambat kinerja perusahaaan dan menjaga kualitas. Ketepatan waktu juga akan menciptakan kepercayaan terhadap tenaga kerja di perusahaan.

Analisis Kelayakan pada Pengupahan PT. Mahakam Kencana Intan Padi

\section{Kelayakan Tenaga Kerja.}

Seperti yang disampaikan Personalia di PT Mahakam Kencana Intan Padi

"...kalau boleh bilang untuk kelayakan bagi para tenaga kerja, sejauh ini kantor kami tidak pernah salah sasaran untuk menempatkan seseorang dengan pekerjaan yang tidak sesuai, kami juga selalu memberikan penghargaan berupa tunjangan-tunjangan pada karyawan/pekerja yang sudah mempunyai nilai lebih dan kriteria tertentu."

\section{Kelayakan Perusahaan} dari wawancara dari Kepala Personalia atau HRD sebagai berikut;

"...Semuanya sudah berdasarkan peraturan Gubenur Jatim no.72 th 2012 tentang upah minimum kabuten/kota di jawa timur".

Hasil dari wawancara di atas juga didukung dengan wawancara kedua kepada Kepala Personalia yang diperoleh hasil sebagai berikut;

"...selama ini yang terjadi di perusahaan ini tidak pernah ada pembayaran yang tidak sesuai dengan kontrak karena ketika ada kejadian seperti itu pastilah ada oknum oknum yang sengaja mengambil keuntungan, sedangkan kita tidak pernah mentolerir kepada siapa saja oknum yang memanipulasi hingga meyebabkan pembayaran tenaga kerja yang tidak sesuai dengan kontrak".

Berdasarkan hasil wawancara yang diperoleh di atas menunjukkan bahwa upah yang diberikan kepada tenaga kerja selama ini belum pernah tidak sesuai dengan kontrak dan perusahaan tidak menindak bagi siapa saja yang mengambil keuntungan. Maka PT. Mahakam Kencana Intan Padi juga mentaati peraturan daerah dengan terbuktinya wawancara pembayaran tidak pernah tidak sesui dengan kontrak tersebut.

menurut Yusuf Qardhawi (2005) ada beberapa aspek secara garis besar yaitu 1) Tanggung jawab perusahaan terhadap 
Alim, et al/Jurnal Ekonomi Syariah Teori dan Terapan Vol. 5 No. 6 Juni 2018: 499-510; SISTEM PENGUPAHAN OUTSOURCING DALAM PERSPEKTIF ISLAM (STUDI KASUS PADA PT. MAHAKAM

KENCANA INTAN PADI SURABAYA)

sistem penggajian, 2) Penegakan pekerja pada sistem penggajian 3) Pencegahan terhadap perbuatan-perbuatan yang melanggar.

Selanjutnya aspek kelayakan perusahaan pada sistem pengupahan PT. Mahakam Kencana Intan Padi menurut pandangan Yusuf Qardhawi ada kesesuaian dengan peraturan daerah dan tanggung jawab perusahaan. Selanjutnya pada penegakkan pekerja pada sistem penggajian dan pencegahan pada perbuatan-perbuatan yang melanggar terwujud ada penegakan di perusahaan berdasarkan wawancara dari kepala personalia di atas. Jadi hasil analisa dari beberapa data yang diperoleh di atas maka dapat dikatakan bahwa PT. Mahakam Kencana Intan Padi termuat nilai-nilai Islam di dalamnya.

\section{v. SIMPULAN DAN SARAN}

\section{Simpulan}

1. Upah yang ditetapkan PT. Mahakam sudah sesuai dengan nilai-nilai Islam yang didasarkan dengan kelayakan upah dalam pemenuhan kebutuhan. Seperti dalam hadits Rasulullah Saw. Menyuruh majikan memberikan upah yang layak pada pekerja. Jadi PT. Mahakam pengupahan berdasarkan UMR Kota Surabaya sebesar Rp. 2710.000,-. UMR kota Surabaya dinilai pemerintah sebagai acuan pengupahan yang dapat dikatakan layak.

2. Tinjauan aspek Kelayakan dan Keadilan dalam Prespektif Islam a. Perbandingan jabatan tenaga kerja PT. Mahakam Kencana Intan Padi juga sesuai dengan prespektif Islam yang terwujud dalam al-Qur'an surat Yusuf ayat 72 upah disesuaikan jerih payahnya. Dengan perbedaan tugas antara koordinator sekuriti dan tenaga sekuriti juga memberikan perbedaan gaji tambahan tetapi tidak merubah gaji pokok.

b. PT. Mahakam Kencana Padi menjalankan ketepatan waktu dalam pembayaran gaji. Hal tersebut sesuai dengan Hadits Nabi Muhammad Saw. yang maksudnya melarang memperlambat bayaran karena itu sebagai perbuatan dzalim.

c. Dalam sistem pengupahan PT. Mahakam Kencana Intan Padi juga terdapat peran pemerintah berdasarkan peraturan peraturan Gubenur Jatim no.72 th 2012 dan Pengontrolan pemerintah dengan adanya kerjasama pelaksanaan hukum pemerintah di perusahaan. Hal tersebut juga sesuai dengan prespektif Islam menurut pendapat Ulama Fiqih yaitu Yusuf Qardhawi bahwa ada bebera peran pemerintah yaitu tanggung jawab negara, penegakkan sistem pengupahan dan pencegahan perbuatan yang melanggar.

PT. Mahakam Kencana Intan padi bukan perusahaan berbasis syari'ah. Tetapi dari hasil kesimpulan penelitian di atas maka sistem pengupahan di PT. Mahakam Kencana Intan Padi sesuai dengan prespektif Islam. Prespektif Islam 
Alim, et al/Jurnal Ekonomi Syariah Teori dan Terapan Vol. 5 No. 6 Juni 2018: 499-510; SISTEM PENGUPAHAN OUTSOURCING DALAM PERSPEKTIF ISLAM (STUDI KASUS PADA PT. MAHAKAM

KENCANA INTAN PADI SURABAYA)

dalam artian nilai-nilai Islam yang ditinjau

berdasarkan kesesuaian ayat al-Qur'an,

Hadits dan Ulama Islam.

\section{Saran}

Adanya sistem informasi penggajian kepada seluruh tenaga kerja PT. Mahakam Kencana Intan Padi. Hal tersebut ditujukan supaya menghindari prasangka-prasangka negatif terhadap perusahaan. Jika informasi belum merata di seluruh tenaga kerja dikhawatirkan memperlambat kinerja perusahaan. Informasi masalah gaji dengan karyawan juga dapat mengetahui hal-hal yang belum dicapai dalam pemenuhan kesejahteraan dan sebanding dengan apa yang mereka kerjaan.

Perusahaan juga dapat melakukan survey dengan perusahaan-perusahaan lain yang berbasis syar'iah, agar dapat berkompetisi mengenai gaji tenaga kerja dan membuktikan bahwa perusahaan ini menerapkan nilai-nilai Islam dalam sistem pengupahannya.

\section{DAFTAR PUSTAKA}

Abdurrahman Al-Maliki. 2009. Politik Ekonomi Islam, Bogor: Al-Azhar Press

Baqir Syarif Al- Qasyari. 2007.Keringat Buruh, Jakarta: Al-Huda. Hal 159

Egi, Sudjana. 2002. Bayarlah Upah Sebelum Keringat Kering, Jakarta: APMI, hal 41.

Ibid, Surat At-Taubah ayat 105.

Ibid, Surat Yusuf ayat 72.
M. A Maman. 1998. Ekonomi Islam Theori dan Praktek, Jakarta.Edisi 5. Halaman 116

Muba, Wang. 2010. Tenaga Kerja Outsourcing, Artikel Diakses dari $\mathrm{http//wangmuba.com.}$

Pt.mahakamkencanaintanpadi.co.id. di akses 19 Juni 2014

Qardhawi (al), Yusuf. Peran Nilai dan Moral dalam Perekonomian Islam. Jakarta: Robbani Press, 2001.

Saeful Rahmat, Pupu. 2009. Penelitian Kualitatif, Jakarta: Equilibrium Vol.5 No. 9

Sugiarto, Rudi. 2012. Skripsi S1 jurusan Ekonomi Islam UIN syarif Hidayatullah. Sistem Pengupahan pada PT Permata Indonesia dalam Ekonomi Islam. Jakarta.

Sugiyono. (2012). Metode Penelitian Kualitatif dan R\&D. Bandung: Alfabeta.

Syam, Zulkhaeril. 2011. Pengupahan Karyawan Dalam Perspektif Fiqih Muamalah (Studi Kasus Pada Home Idustri, konveksi kalibata Jakarta Selatan). Jakarta.

Wangsa, Sugianto dan Ming Kuang, Tan. 2011. Penelitian Kualitatif dengan studi kasus. Jakarta.

Yin, Robert K. 2010. Studi Kasus: Desain dan Metode, Jakarta. PT. Raja Grafindo Persada 
Alim, et al/Jurnal Ekonomi Syariah Teori dan Terapan Vol. 5 No. 6 Juni 2018: 499-510; SISTEM PENGUPAHAN OUTSOURCING DALAM PERSPEKTIF ISLAM (STUDI KASUS PADA PT. MAHAKAM KENCANA INTAN PADI SURABAYA) 